\title{
When will we get the COVID-19 vaccine?
}

\author{
Siukan Law \\ Department of Science, School of Science and Technology, The Open University of Hong Kong, Ho Man Tin, Kowloon, Hong Kong
}

[Received: 17 June 2020; Accepted: 28 June 2020]

Coronavirus disease-2019 (COVID-19) has been spread all around the world and confirmed severe acute respiratory syndrome coronavirus 2 (SARS$\mathrm{CoV}-2$ ) is the virus strain which as a causative agent. How can we quickly develop a vaccine against SARS-CoV-2? It plays a significant rule in the inhibition, prevention of viruses, and contribution to the control of an outbreak. However, this becomes a huge challenge for scientists because of the limited information about SARS-CoV-2 including its genomics, structural biology, virology, pathology, epidemiology, and the specific immune response ${ }^{1}$. The average time for vaccine development taken from the preclinical phase, clinical trials phase I, II and III up to approve by Food and Drug Administration (FDA) and market registration required 10.71 years ${ }^{2}$.

On the $21^{\text {st }}$ of February in 2020, 120 whole-genome sequences of SARS-CoV-2 are analyzed from the GISAID database ${ }^{3}$. Recombinant DNA technology is the most common method to design and create a SARS-CoV-2 antigen as well as embedding it within a primate adenovirus vector. The vaccine candidates must trigger favorable T-cell responses, rather than relying solely on antibody responses, said by Sarah Gilbert $^{4}$. SARS-CoV-2 replicates at the binding site on the surface of target cells such as bronchial and type 2 alveolar epithelial cells processed by the type 2 transmembrane protease (TMPRSS2), leading to the cleavage of angiotensin-converting enzyme 2 (ACE2) receptor and activation of the viral spike protein $^{5-6}$. The anticipated vaccine produces a neutralizing antibody that blocks the binding site of viral spike protein and resists its uptake to the angiotensin-converting enzyme 2 (ACE2) receptor. As the vaccine has high protein expression levels, it could also induce a strong immune response and remain stable for a long time ${ }^{7}$.
According to the World Health Organization (WHO) draft landscape of COVID-19 candidate vaccines, there are 5 candidate vaccines in clinical evaluation up to $20^{\text {th }}$ of April in 2020 consist of Adenovirus Type 5 Vector from CanSino Biological incorporated company, DNA plasmid vaccine Electroporation device from Inovio Pharmaceuticals, Inactivated virus from Beijing Institute of Biological Products, Inactivated virus plus alum from Sinovac, LNP encapsulated mRNA-1273 from Moderna ${ }^{8}$. Sinovac is one of the candidate vaccine companies and its researchers began using eight rhesus macaque monkeys with two different dosages of purified inactivated SARS-CoV-2 virus vaccine (PiCoVacc) for human trials on 16th of April in 2020 $0^{9}$. The studies have been found that vaccine with $3 \mu \mathrm{g}$ or $6 \mu \mathrm{g}$ per dose for immunization which provided partial or complete protection against the SARS-CoV-2 challenge in rhesus macaque monkeys, also without any antibody-dependent enhancement of infection ${ }^{10}$.

However, there are some concerns about this vaccine such as i) the number of rhesus macaque monkeys for investigation are too small to yield statistically significant and reliable results; ${ }^{9}$ ii) the immune response of monkeys might be different from that of humans. It cannot develop the most severe symptoms infected by SARS-CoV-2 ${ }^{11}$; iii) no shreds of evidence to support that there are no aberrant immune responses after vaccination of low levels antibodies particularly in lung damage. If animals are injected with pathogens, it might be enhancing the infection and causing pathology in the lungs or other organs based on past investigation ${ }^{12}$.

All of the above information demonstrates that much more work needs to be done for the COVID-19 vaccine development including increasing the number of animals in clinical trials to collect 
statistically significant data; defining the best animal model for studying SARS-CoV-2 as well as proving the COVID-19 vaccine safety and effectiveness in human. Fortunately, there is no evidence for SARS$\mathrm{CoV}-2$ is mutating at present but the SARS-CoV-2 variants are the possible challenge for vaccine development.

\section{References}

1. Lurie N, Saville M, Hatchett R, Halton J. Developing Covid19 Vaccines at Pandemic Speed 2020

2. Pronker ES, Weenen TC, Commandeur H, Claassen EHJHM Osterhaus ADME. Risk in Vaccine Research and Development Quantified. PLoS ONE 2013;8(3):e57755

3. Ahmed SF, Quadeer AA, McKay MR. Preliminary Identification of Potential Vaccine Targets for the COVID-19 Coronavirus (SARS-CoV-2) Based on SARS-CoV Immunological Studies. Viruses 2020;12:254

4. Lane R. Sarah Gilbert: carving a path towards a COVID-19 vaccine. Lancet 2020;395(102 32):1247

5. Glowacka I, Bertram S, Muller MA, Allen P, Soilleux E et al. Evidence that TMPRSS2 Activates the Severe Acute Respiratory Syndrome Coronavirus Spike Protein for Membrane Fusion and Reduces Viral Control by the Humoral Immune Response. J Virol 2011;85:4122-4134

6. Heurich A, Hofmann-Winkler H, Gierer S, Liepold T, Jahn O, Pohlmann S. TMPRSS2 and ADAM17 Cleave ACE2 Differentially and Only Proteolysis by TMPRSS2 Augments Entry Driven by the Severe Acute Respiratory Syndrome Coronavirus Spike Protein. J Virol 2014;88:1293-1307

7. Le TT, Andreadakis Z, Kumar A, Román RG, Tollefsen S et al. The COVID-19 vaccine development landscape. Nat Rev Drug Discov 2020;19(5):305-306

8. World Health Organization. Draft landscape of COVID-19 candidate vaccines. Retrieved April 21, 2020, from https://www.who.int/blueprint/priority-diseases/keyaction/novel-coronavirus-landscape-ncov.pdf; Accessed 1 June 2020

9. Cohen Jon. COVID-19 vaccine protects monkeys from new coronavirus, Chinese biotech reports. Retrieved April 23, 2020, from https://www.sciencemag.org/news/2020/04/covid-19vaccine-protects-monkeys-new-coronavirus-chinese-biotechreports; Accessed 1 June 2020

10. Gao Q, Bao L, Mao H, Wang L, Xu K et al. Rapid development of an inactivated vaccine for SARS-CoV-2. BioRxiv 2020

11. Haigwood NL, Walker CM. Commissioned Paper: Comparison of Immunity to Pathogens in Humans, Chimpanzees, and Macaques. National Academies Press (US) 2011; https://www.ncbi.nlm.nih.gov/books/NBK91442/

12. Song Z, Xu Y, Bao L, Zhang L, Yu P et al. From SARS to MERS, Thrusting Coronaviruses into the Spotlight. Viruses 2019;11(1):59

[Bangladesh Journal of Infectious Diseases, June 2020; 7(1):42-43]

Correspondence: Dr. Siukan Law, Department of Science, School of Science and Technology, The Open University of Hong Kong, Ho Man Tin, Kowloon, Hong Kong; Email: siukanlaw@ hotmail.com. Conflict of interest: The author has no conflicts of interest to disclose.

Funding agency: The author received no funding source/grants or other materials support for this work.

How to cite this article: Law S. When will we get the COVID-19 vaccine? Bangladesh J Infect Dis 2020;7(1):42-43

Copyright: (02020. Law S. Published by Bangladesh Journal of Infectious Diseases. This article is published under the Creative Commons $\quad$ CC $\quad$ BY-NC L License (https://creativecommons.org/licenses/by-nc/4.0/). This license permits use, distribution and reproduction in any medium, provided the original work is properly cited, and is not used for commercial purposes. 